\title{
CSR REPORTING BY THE TOP10 ESTONIAN COMPANIES RATED BY PROFIT GROWTH
}

\author{
Natalja Gurvits ${ }^{1}$, Emilia Startseva $^{2}$, Inna Sidorova ${ }^{3}$ \\ ${ }^{1,2}$ Tallinn University of Technology, Estonia \\ ${ }^{3}$ BGC Brokers LP, United Kingdom \\ cross $^{\text {ref }}$ http://dx.doi.org/10.5755/j01.em.19.3.7725
}

\begin{abstract}
Nowadays more and more companies all over the world have been providing Corporate Social Responsibility (CSR) related information. As a result many companies today implement CSR strategies and disclose respective information either via standalone CSR reporting or through their websites. In Estonia today there are no governmental requirements related to the disclosure of nonfinancial information, but companies quoted at the Tallinn Stock Exchange have already started to prepare standalone CSR reports and include non-financial information into their annual reports. Most companies provide CSR related information on their websites making it visible and easily accessible for the users. This article presents the survey of CSR reporting by the Top10 Estonian companies (ranked by profit growth) conducted by studying annual reports and websites of the selected companies for the year 2012. The criteria for the choice, and presentation of information were tailored to the template developed by Ashridge Business School. The research results revealed that there is a growing trend of CSR reporting among the leading Estonian business companies, however companies are not willing to prepare standalone CSR reports and prefer to disclose CSR related information via either website and/or via annual report, which may be related to such factors as time, human resources and practical knowledge and skills.
\end{abstract}

The type of the article: Research report.

Keywords: Corporate Social Responsibility, standalone report, sustainability, website.

JEL Classification: M14.

\section{Introduction}

In the last decades the subject of Corporate Social Responsibility (CSR) has been steadily attracting worldwide interest and has become more popular than ever. Many business firms have started to assume social and political responsibilities that go beyond legal requirements and fill the regulatory vacuum in global governance (Scherer \& Palazzo, 2011). As a result many companies today implement CSR strategies and disclose respective information either via standalone CSR reporting or through their websites.

CSR related information and CSR reporting have been rapidly developing across the world during the last decade. Numerous studies are dedicated to the investigation of various factors influencing the CSR reporting as well as the type, sort and amount of information disclosed by various companies in different sectors. Studies by I. Lock and P. Seele (2013) analyzed the CSR reporting in chemicals, banking and insurance industries and revealed that Swiss chemical companies are doing quite well in the CSR reporting, while still further standardization of the CSR in Europe was required. Studies of CSR in the international insurance industry demonstrated that there existed significant differences between different types of insurers and between countries. The results of studies made by Scholtens (2011) also suggested that social and ethical aspects of CSR are better integrated in the business of insurers than the environmental aspects (Scholtens, 2011). This study also found that financial conglomerates perform better than all other types of insurance companies. 
Y. Kamal and C. Deegan (2013) studies the social and environment-related governance disclosure practices in the textile and garment industry in the country of Bangladesh. The study revealed that such disclosures are not somewhat strange and unknown, but "still fall short of what would appear to be expected by the international community". The results also suggest limited accountability and transparency in relation to social and environment-related governance practices within a developing country context (Kamal \& Deegan, 2013).

CSR reporting quality and the level of disclosure are totally different across countries. S. Young and M. Marais (2012) studied the influence of national institutions and industry characteristics on CSR reporting compared. Their findings suggest CSR reporting is also stronger in high-risk industries than in low-risk industries. It also found that industry characteristics override the influence of national institutions in high-risk industries (Young \& Marais, 2012).

C. Noronha, S. Tou, M. I. Cynthia and J. J. Guan (2013), did research on CSR reporting in China and arrived to the conclusion that such reporting was in the preliminary stage in this country. J. Graafland and L. Zhang (2014) also stated that the attention to social and environmental aspects of CSR is still far beyond from high. The studies of L. Kuo, C.-C. Yeh and H.-C. Yu (2012) also indicated that "environmentally sensitive industries (ESIs)" and state-owned enterprises are significantly more committed to environmental information disclosure, which is also the case for several Estonian companies. It should be noted that in Estonia the content of CSR reporting varies as depending on the nature of business some companies choose either social or environmental information to be disclosed. However, in some cases companies also prepare standalone environmental reports in addition to the standalone CSR reporting in order to outline the importance of disclosing such information as waste management, energy consumption and compliance with environmental regulations and requirements.

A. Romolini, S. Fissi and E. Gori (2012) analyzed the CSR reports of the Italian companies making up the FTSE ECPI Leaders Index of the Italian Stock Exchange and the findings demonstrated a good level of disclosure with the improving quality level.

Studies also investigated whether CSR reporting depends on the public policy of the selected country. D. Beare, R. Buslovich and C. Searcy (2013) in their study held interviews with 35 different Canadian corporations that produce sustainability reports, focusing on the impact of public policy on the sustainability reporting. The majority of participants stated that their corporation's sustainability reporting was not influenced by public policy mainly due to the lack of the direction from government (Beare, Buslovich \& Searcy, 2013).

Some studies claimed that the governmental regulation and additional pressure on CSR reporting produce quite good results and make companies more concerned about this matter. E. R. G. Pedersen, P. Neergaard, J. T. Pedersen and W. Gwozdz (2013) explored the response of Danish companies to new governmental regulation on compulsory CSR reporting and their studies confirmed that government pressure had an impact on the CSR reporting practices. Therefore it may be a good practice to encourage the implementation CSR reporting in various EU countries.

Studies also bring out that CSR reporting depends on the ownership type. This interrelation is explored by L. Dam and B. Scholtens (2012) in their studies of how different owners relate to CSR. The study revealed that ownership by employees, individuals, and firms is associated with relatively poor corporate social policies of the firms they invest in. In contrast, the holdings by banks and institutional investors as well as those by the state appear to be neutral in this respect (Dam \& Scholtens, 2012).

It should also be mentioned that, as depicted in numerous studies, CSR largely depends on the culture and political background of the selected country. According to M. Gjølberg (2010), preexisting political-economic institutions and cultural norms deeply affect the interpretation of CSR. This in turn leads to the CSR accounting and reporting model implemented and used in the particular country (Gjølberg, 2010). Company policy is largely determined by the management board. The nature and the scope of the CSR reporting depend of the management desire and efforts to implement the CSR policy into the companies' everyday business activities. This assumption is confirmed by an interesting and outstanding study carried out by B. Fernandez-Feijoo, S. Romero, and S. Ruiz-Blanco (2013), who explored the relationship between sustainability reporting and the 
existence of at least three women on the board of directors. The results of the study show that in countries with a higher proportion of boards of directors with at least three women, the levels of CSR reporting are higher (Fernandez-Feijoo, Romero \& Ruiz-Blanco, 2013).

In October 2011 the European Commission published a new policy on corporate social responsibility. The Commission also defines corporate social responsibility as "the responsibility of enterprises for their impacts on society". To fully meet their social responsibility, enterprises "should have in place a process to integrate social, environmental, ethical, human rights and consumer concerns into their business operations and core strategy in close collaboration with their stakeholders" (EU Commission, 2011).

CSR reporting is not yet compulsory within the EU countries; however, these disclosures are becoming more and more relevant and appear in the reports of most leading companies in each country. European law makes the following requirement on companies: "To the extent necessary for an understanding of the company's development, performance or position, the analysis [in the annual review] shall include both financial and, where appropriate, non-financial key performance indicators relevant to the particular business, including information relating to environmental and employee matters" (The European Parliament and the Council, 2003). There is also a notably growing trend of issuing standalone CSR reports and/or social and/or environmental reports, which provide additional non-financial information about the performance of the company.

Also worth mentioning is a 2011 study into CSR reporting practices of the EU companies. This study, financed by the European Commission's Directorate-General for Employment and Social Affairs, provides an overview of current practices and challenges in sustainability reporting by European companies. This study revealed that when companies report on their corporate social responsibility (CSR), it encourages more companies to engage in these practices. The study also finds that reader's needs are best met when: reporting is regulated, CSR reporting is integrated with financial reporting, stakeholders are more involved in reporting (EU Commission Sustainability..., 2011).

In Estonia the CSR framework has been in development since 2004, which led to the establishment of Responsible Business Forum in Estonia in 2004-2006. It is, a non-profit organisation with an aim of furthering CSR in Estonian society through being the centre of competence building and communication on CSR. Building on the outcomes of the multistakeholder dialogue, Responsible Business Forum in Estonia continues its action through fostering CSR-related initiatives as well as providing related consultations (http://www.csr.ee/). The organization also offers various advisory services on Corporate Sustainability and Responsibility like strategic consulting, trainings and workshops for managers and employees, community based projects, etc. Today more and more companies start to implement the CSR strategy and to disclose CSR related information by either preparing standalone CSR reports or providing this information on the company's website. 0There has been an increase in the number of social reporting requirements driven by regulatory bodies and stock exchanges around the world that have played a key role in advancing the field of social reporting (Global CSR Disclosure Requirements, n.d.).

The European Commission strongly encourages all member countries to report and disclose CSR related information as good disclosure of non-financial information enables investors to contribute to a more efficient allocation of capital and better achieve longer-term investment goals. It can also help to make enterprises more accountable and contribute to higher levels of citizen trust in business (EU Commission, 2011).

According to Yvo de Boer KPMG's Global Chairman, the debate on whether companies should report on CR or not is dead and buried. CR reporting appears to be standard business practice all over the world - even in those geographic regions and industry sectors that only two years ago lagged behind. The questions companies should ask themselves now, and which we have endeavored to answer in this publication, are "what should we report on?" and "how should we report it?" And, most importantly, "how can we best use the process of reporting to generate maximum value both for our shareholders and for our other stakeholders?" (KPMG, 2013).

The KPMG Survey also revealed that America overtook Europe as the leading reporting region. Asia Pacific saw the most significant increase due to a jump in CR reporting rates in 
countries such as India, Singapore and Australia, and new countries with high reporting rates joining the survey. Rates remained static in Europe and dropped in the Middle East \& Africa, largely due to a number of countries with low reporting rates joining the survey for the first time (KPMG, 2013).

In Estonia today there are no governmental requirements related to the disclosure of nonfinancial information, but companies quoted at the Tallinn Stock Exchange have already started to prepare standalone CSR reports and include non-financial information into their annual reports. Most companies provide CSR related information on their websites making it visible and easily accessible for the users.

These developments have influenced the choice of the topic for this research. The subject of the research is CSR information from the annual reports and websites of the TOP10 Estonian companies by profit growth, as rated by the leading Estonian business newspaper "Äripäev". The aim of the present research is to find out whether Estonian TOP 10 leading business companies by profit growth are implementing CSR reporting practices and how they prefer to present this information to the stakeholders.

\section{Methodology}

Within the framework of this article the authors analysed CSR information provided by the Top10 Estonian companies by Profit Growth as of year 2012. According to authors' opinion, increased competition should serve as motivation for the companies to supply non-financial information concerning their activities to existing and potential stakeholders. The authors studied annual reports and the websites of the selected companies for the year 2012. Authors have studied the Estonian version of annual reports of the selected 10 companies submitted to the state via ereporting system and if available also the English version of the annual report in order to find CSRrelated information in any of the sections. Authors have also investigated the information published and publicly available on the companies' website in order to figure out what CSR-related information is supplied to the stakeholders as in authors' opinion, for a customer, a company's website serves as the most accessible and important source of information about the company, while annual report as a source of information about CSR activity is more tailored to professionals. The criteria for the choice and presentation of information were tailored to the template developed by Ashridge Business School: A - Leadership, vision and values; B -Marketplace activities; C Workforce; D - Suppliers; E - Stakeholders engagement; F - Community activities; G Environmental activities (Ashridge, 2005). For the current research authors have modified the selected template and have chosen the following criteria A - Leadership, vision and values; B Customers related activities, C - Employees related activities; D - Suppliers related activities; E Shareholders and investors related activities; F- Community related activities; G - Environment related activities. Table 1 presents the selected companies in the fastest growing order as published by the leading Estonian business newspaper "Äripäev".

Table 1. Details of Top10 Estonian Companies by profit Growth as of Year 2012

\begin{tabular}{|l|l|c|c|}
\hline No. & \multicolumn{1}{|c|}{ Name (Trade name) } & Website & Profit growth, th $\boldsymbol{€}$ \\
\hline 1. & SWEDBANK AS & www.swedbank.ee & 65900 \\
\hline 2. & HOOLEKANDETEENUSED AS & www.hoolekandeteenused.ee & 21494 \\
\hline 3. & MERKO EHITUS AS & www.merko.ee & 21106 \\
\hline 4. & Skinest Rail AS & www.skinest.ee & 16559 \\
\hline 5. & Spacecom AS & www.spasecom.ee & 14606 \\
\hline 6. & Statoil Fuel \& Retail Eesti AS & www.statoil.ee & 14165 \\
\hline 7. & Elering AS & www.elering.ee & 12724 \\
\hline 8. & Skanska AS & www.skanska.ee & 12229 \\
\hline 9. & MAXIMA Eesti OÜ & www.olympic-casino.com & 9572 \\
\hline 10. & Olympic Entertainment Group AS & \\
\hline
\end{tabular}

Source: Rating for year 2012 published by the leading Estonian business newspaper "Äripäev 
The Table 1 lays out following information: name (trade name) of the company, profit growth for the year 2012 based on information published by the leading Estonian business newspaper "Äripäev" and the company website.

\section{Results}

The results of the survey clearly indicate that for the year 2013 only in case of two companies there was present a standalone sustainability report, but it was issued by the parent company for the whole group. However all companies provide CSR related information through either respective websites or annual report. Table 2 demonstrates breakout within the main groups of CSR activities.

Table 2. CSR Reporting Information of Top10 Estonian Companies by Profit Growth

\begin{tabular}{|c|l|c|c|}
\hline Group & \multicolumn{1}{|c|}{ Type of CSR Activity } & $\begin{array}{c}\text { No. of companies reporting } \\
\text { via website }\end{array}$ & $\begin{array}{c}\text { No. of companies reporting via } \\
\text { annual report for the year 2012 }\end{array}$ \\
\hline A & Leadership, vision and values & 10 & 7 \\
\hline B & Customers related & 10 & 7 \\
\hline C & Employees related & 9 & 5 \\
\hline D & Suppliers related & 7 & 7 \\
\hline E & Stakeholders and investors related & 4 & 6 \\
\hline F & Community related & 9 & 6 \\
\hline G & Environmental related & 8 & 8 \\
\hline
\end{tabular}

Source: Websites and annual reports for year 2012 and 2013of the selected companies

The research results confirm that there is a growing trend of CSR reporting among leading Estonian business companies, however companies are not willing to prepare standalone CSR and prefer to disclose CSR related information via either website and/or annual report. However, it is worth mentioning that in the process of research authors used the "substance over form" approach towards the selected companies and were not looking for CSR related sections in the annual reports but carefully reading the whole text of the report to extract CSR related disclosures from different sections.

Analysis of information provided through companies' websites and annual reports show that the most popular areas of CSR related disclosures of companies are community, employee and the environmental related activities.

\section{Discussion and Conclusions}

The aim of this present research has been achieved, it can be stated that top 10 Estonian companies by Profit Growth are in line with the latest CSR trends and practices and are successfully implementing CSR and indeed pay attention to the matters of social responsibility through either annual reporting and/or respective website. It also seems that these companies prefer to disclose information via website or annual report, which may be related to the fact that preparation of the standalone CSR report requires more time, human resources and practical knowledge and skills.

It should also be mentioned that authors are of the opinion that in Estonia there is no clear idea of who should prepare the standalone CSR report or the corresponding section of the annual report. Therefore not all the reports include CSR related sections and information on CSR can be spotted virtually anywhere. Environmental related disclosures are less popular as many companies, whose business is not directly related to environmental impact, consider this least important. This may be explained by the fact that for most companies CSR is mainly associated with community, charity and people with reporting of the respective activities prevailing.

The authors are of the opinion that today in the conditions of increased competition Estonian companies should pay more attention to the type and form of CSR reporting to make information easily accessible and understandable for all types of stakeholders as their awareness affects success of the companies. 


\section{References}

Annual reports of selected Estonian companies for the year 2012.

Ashridge Business School UK. (2005).Catalogue of CSR Activities: A road overview. Copenhagen, Denmark: Danish Commerce and Companies Agency.

Beare, D., Buslovich, R. and Searcy, C. (2013), Linkages between Corporate Sustainability Reporting and Public Policy. Corp. Soc. Responsib. Environ. Mgmt. doi: 10.1002/csr.1323

Dam, L. \& Scholtens, B. (2012), Does Ownership Type Matter for Corporate Social Responsibility? Corporate Governance: An International Review, 20: 233-252. doi: 10.1111/j.1467-8683.2011.00907

EU Commission (2011). Corporate Social Responsibility. Retrieved 27/01/2014 from http://ec.europa.eu/enterprise/policies/sustainable-business/corporate-social-responsibility/

EU Commission. (2011). Sustainability Reporting. Retrieved 27/01/2014 from http://ec.europa.eu/social/main.jsp?langId=en\&catId=89\&newsId=1013\&furtherNews=yes.

Fernandez-Feijoo, B., Romero, S. \& Ruiz-Blanco, S. (2013), Women on Boards: Do They Affect Sustainability Reporting?. Corp. Soc. Responsib. Environ. Mgmt. doi: 10.1002/csr.1329

Gjølberg, M. (2010), Varieties of corporate social responsibility (CSR): CSR meets the "Nordic Model". Regulation \& Governance, 4: 203-229. doi: 10.1111/j.1748-5991.2010.01080

Global CSR Disclosure Requirements (n.d.). Retrieved 29/01/2014 http://hausercenter.org/iri/about/globalcsr-disclosure-requirements.

Graafland, J. \& Zhang, L. (2014), Corporate social responsibility in China: implementation and challenges. Business Ethics: A European Review, 23: 34-49. doi: 10.1111/beer.12036

Kamal, Y. \& Deegan, C. (2013), Corporate Social and Environment-related Governance Disclosure Practices in the Textile and Garment Industry: Evidence from a Developing Country. Australian Accounting Review, 23: 117-134. doi: 10.1111/j.1835-2561.2012.00205

KPMG. (2013). International Survey of Corporate Responsibility Reporting 2013. Retrieved 27/01/2014 from http://www.kpmg.com/Global/en/IssuesAndInsights/ArticlesPublications/corporateresponsibility/Documents/corporate-responsibility-reporting-survey-2013.pdf.

Kuo, L., Yeh, C.-C. \& Yu, H.-C. (2012), Disclosure of Corporate Social Responsibility and Environmental Management: Evidence from China. Corp. Soc. Responsib. Environ. Mgmt, 19: 273-287. doi: $10.1002 / \mathrm{csr} .274$

Lock, I. \& Seele, P. (2013), Analyzing Sector-Specific CSR Reporting: Social and Environmental Disclosure to Investors in the Chemicals and Banking and Insurance Industry. Corp. Soc. Responsib. Environ. Mgmt. doi: 10.1002/csr.1338

Noronha, C., Tou, S., Cynthia, M. I. \& Guan, J. J. (2013), Corporate Social Responsibility Reporting in China: An Overview and Comparison with Major Trends. Corp. Soc. Responsib. Environ. Mgmt, 20: 29-42. doi: 10.1002/csr.1276

Pedersen, E. R. G., Neergaard, P., Pedersen, J. T. \& Gwozdz, W. (2013), Conformance and Deviance: Company Responses to Institutional Pressures for Corporate Social Responsibility Reporting. Bus. Strat. Env., 22: 357-373. doi: 10.1002/bse.1743

Romolini, A., Fissi, S. \& Gori, E. (2012), Scoring CSR Reporting in Listed Companies - Evidence from Italian Best Practices. Corp. Soc. Responsib. Environ. Mgmt. doi: 10.1002/csr.1299

Scherer, A. G. \& Palazzo, G. (2011), The New Political Role of Business in a Globalized World: A Review of a New Perspective on CSR and its Implications for the Firm, Governance, and Democracy. Journal of Management Studies, 48: 899-931. doi: 10.1111/j.1467-6486.2010.00950

Scholtens, B. (2011), Corporate social responsibility in the international insurance industry. Sust. Dev., 19: 143-156. doi: 10.1002/sd.513

The European Parliament and the Council. (2003). Retrieved 27/01/2014 from

http://eur-lex.europa.eu/LexUriServ/LexUriServ.do?uri=OJ:L:2003:178:0016:0022:EN:PDF

Young, S. \& Marais, M. (2012), A Multi-level Perspective of CSR Reporting: The Implications of National Institutions and Industry Risk Characteristics. Corporate Governance: An International Review, 20: 432-450. doi: 10.1111/j.1467-8683.2012.00926. 